College of William \& Mary Law School William \& Mary Law School Scholarship Repository

1994

\title{
Rediscovering Nonjusticiability: Judicial Review of Impeachments after Nixon
}

Michael J. Gerhardt

\section{Repository Citation}

Gerhardt, Michael J., "Rediscovering Nonjusticiability: Judicial Review of Impeachments after Nixon" (1994). Faculty Publications. 983.

https://scholarship.law.wm.edu/facpubs/983

Copyright c 1994 by the authors. This article is brought to you by the William \& Mary Law School Scholarship Repository. 


\title{
Duke Law Journal
}

\begin{tabular}{l}
\hline VOLUME $44 \quad$ NOVEMBER 1994 \\
\hline \\
REDISCOVERING NONJUSTICIABILITY: \\
JUDICIAL REVIEW OF \\
IMPEACHMENTS AFTER NIXON
\end{tabular}

\author{
MICHAEL J. GERHARDT $\dagger$ \\ INTRODUCTION
}

Few constitutional canons are criticized more often than the political question doctrine. It has been called "deceptive," "unwarranted," "an enigma,", "useless,"4 and "mixed up and inconsistent." The fact that in the thirty years after the Supreme Court set forth the modern political question doctrine $e^{6}$ it found only one such question ${ }^{7}$ and did not identify any in fourteen other cases $^{8}$

$\dagger$ Professor of Law, Marshall-Wythe School of Law, The College of William and Mary. B.A. Yale University; M.Sc. London School of Economics; J.D. University of Chicago. This Article was prepared as part of a study I conducted under contract as a special consultant to the National Commission on Judicial Discipline and Removal. Although the analysis does not necessarily reflect the views of the Commission members or staff, I am grateful to the Commission members and staff, especially Director Michael Remington, for their probing questions and helpful suggestions, all of which enriched my thinking. I am also grateful for the helpful comments and other assistance I have received from Rebecca Brown, Cynthia Farina, Jill Fisch, Peter Shane, Steve Shiffrin, and Ron Wright. (1976).

1. Louis Henkin, Is There a "Political Question" Doctrine?, 85 Yale L.J. 597, 622

2. Walter Dellinger, The Legitimacy of Constitutional Change: Rethinking the Amendment Process, 97 Harv. L. Rev. 386, 397 (1983).

3. Martin H. Redish, Judicial Review and the "Political Question," 79 Nw. U. L. Rev. 1031, 1031 (1985).

4. Erwin Chemerinsky, Federal JURISDICTION $\& 2.6$, at 127 (1989).

5. Rebecca L. Brown, When Political Questions Affect Individual Rights: The Other Nixon v. United States, 1993 Sup. Ct. Rev. 125, 153.

6. See Baker v. Carr, 369 U.S. 186, 217 (1962).

7. See Gilligan v. Morgan, 413 U.S. 1, 10-12 (1973).

8. See Department of Commerce v. Montana, 112 S. Ct. 1415, 1425-26 (1992); Unit- 
confirmed doubts about the doctrine's viability. In 1993, when the Supreme Court in Nixon v. United States ${ }^{9}$ found that a challenge to the Senate's use of a special committee to do factfinding for an impeachment trial posed a political question, there was therefore reason to consider the decision a milestone in constitutional law. Yet, the response to Nixon has been either condemnation ${ }^{10}$ or silence.

This reaction is troubling. The silence might reflect a begrudging or widespread acceptance of a practice as old as the Constitution of conducting federal impeachments without subsequent judicial review. On the other hand, condemnation inight suggest that the faith of many constitutional law scholars in judicial review may be so deep-seated that they are not prepared to deal with the implications of a revived pohtical question doctrine even if it were limited to the context of impeachment. ${ }^{11}$

In fact, Nixon is significant for two reasons. First, it breathed hife back into the much-maligned pohitical question doctrine, comprising the Court's practice of claiming textual authority, separation of powers concerns, and prudential reasons for not deciding the merits of certain constitutional questions. ${ }^{12}$ In doing so, the Court took a position on an issue-the justiciability of impeachment challenges-that had long divided constitutional schol-

ed States v. Munoz-Flores, 495 U.S. 385, 389-96 (1990); Quinn v. Millsap, 491 U.S. 95 , 102 (1989); Japan Whaling Ass'n v. American Cetacean Soc'y, 478 U.S. 221, 229-30 (1986); Davis v. Bandemer, 478 U.S. 109, 118-27 (1986); County of Oneida v. Oneida Indian Nation, 470 U.S. 226, 248-50 (1985); INS v. Chadha, 462 U.S. 919, 940-43 (1983); Delaware Tribal Business Comm. v. Weeks, 430 U.S. 73, 83-84 (1977); Elrod v. Burns, 427 U.S. 347, 351-53 (1976) (plurality opinion of Brennan, J.); Stanton v. Stanton, 421 U.S. 7, 11 (1975); United States v. Nixon, 418 U.S. 683, 692-97 (1974); Powell v. McCormack, 395 U.S. 486, 516-49 (1969); Reynolds v. Sims, 377 U.S. 533, 582 (1964); Wesberry v. Sanders, 376 U.S. 1, 5-7 (1964).

9. 113 S. Ct. 732,740 (1993).

10. Brown, supra note 5 , at 126 (criticizing Nixon for not respecting judicial review as an integral part of a meaningful separation of powers doctrine to protect judicial independence and individual rights).

11. This attitude was evident in the bulk of the commentary written in the months just prior to Nixon urging the Court to treat challenges to impeachment procedures as justiciable. See, e.g., David O. Stewart, Impeachment by Ignorance, A.B.A. J., June 1990, at 52, 54; Rose Auslander, Note, Impeaching the Senate's Use of Trial Committees, 67 N.Y.U. L. REv. 68, 68-69 (1992); Brendan C. Fox, Note, Impeachment: The Justiciability of Challenges to the Senate Rules of Procedure for Impeachment Trials, 60 GEO. WASH. L. REv. 1275, 1308-09 (1992); Daniel Luchsinger, Note, Committee Impeachment Trials: The Best Solution?, 80 GEo. L.J. 163, 164 (1991).

12. See generally JOHN E. NOWAK \& RONALD D. ROTUNDA, CONSTITUTIONAL LAW $\S 2.15$ (4th ed. 1991) (discussing the political question doctrine). 
$\operatorname{ars}^{13}$ and is basic for understanding the limits of judicial review. Nixon was particularly surprising because it was premised on the Framers' strong distrust of the federal judiciary as an impartial or competent impeachment authority. Second, Nixon recognized that in the area of impeachment, Congress may make constitutional law-i.e., make judgments about the scope and meaning of its constitutionally authorized impeachment functions-subject to change only if it later changes its mind or by a constitutional ainendment. Thus, Nixon raised the issue of whether, without judicial review, Congress is able to make constitutional decisions in a reasonably principled fashion.

This Article explores these ramifications of Nixon as well as the most difficult questions it left open about the prospects for judicial review of impeachment challenges. It aims to show that no area of constitutional law needs to be nonjusticiable more than impeachment, that impeachment is the best example of a political question, because the textual, historical, and structural bases for its nonjusticiability are stronger than those for any other area, includ-

13. Compare Charles BlacK, IMPEACHMENT: A HANDBooK 53-64 (1974) (arguing that judicial review of impeachment is inconsistent with the Constitution) and Ronald D. Rotunda, An Essay on the Constitutional Parameters of Federal Impeachment, 76 KY. L.J. 707, 728 (1987-1988) (noting that impeachment raises issues that satisfy each element of a political question as set forth by the Court in Baker v. Carr, 369 U.S. 186, 217 (1962)) with RaOUl Berger, IMPEACHMENT: THE CONSTItUTIONAL Problems 103-21 (1973) (argumg that constitutional questions, including legislative-executive conflicts, are justiciable) and IRVING BRANT, IMPEACHMENT: TRIALS AND ERRORS 183-87 (1972) (comparing judicial review of impeachment and bills of attainder) and Gerald Gunther, Judicial Hegemony and Legislative Autonomy: The Nixon Case and the Impeachment Process, 22 UCLA L. REV. 30 (1974) (arguing that the Burger Court erred in not treating as a political question President Nixon's asserted claim of executive privilege in the Watergate tapes case) and John D. Feerick, Impeaching Federal Judges: A Study of the Constitutional Provisions, 39 FORDHAM L. REV. 1, 57 (1970) (questioning legislative definition of impeachable offense) and Mark Tushnet, Principles, Politics, and Constitutional Law, 88 MICH. L. REV. 49, 57 (1989) (arguing that Powell v. McCormack, 395 U.S. 486 (1969), compels the conclusion that such questions are justiciable). 
ing foreign affairs. ${ }^{14}$ In other words, impeachment and the political question doctrine make each other possible.

For background, Part I reviews Nixon. Part II explores Nixon's impact on the status of the political question doctrine. Part III examines the two major prospects after Nixon for judicial review of an impeachment challenge. These include limiting judicial review of impeachments altogetler and confining it to claims based on violations of explicit restraints. Part IV makes the case for barring any judicial review of impeachments. This argument is based on an analysis of the implications of judicial review of the most significant impeachment challenges hikely to arise in the future. These potential claims relate to (1) the applicability of the Fifth Amendment Due Process Clause; (2) the Senate's failure to comply with procedural rules such as a uniform burden of proof or set of evidentiary rules; and (3) procedural irregularities in presidential impeachment trials. Part IV suggests tliat the nonjusticiability of each of these challenges depends on the fact-not sufficiently emphasized in the literature on impeachment or political questions-that the Court may not exercise judicial review over an impeachment because Article III precludes it, i.e., that the Court has neither original nor appellate jurisdiction over any impeachment matter. Part IV concludes further that the nonjusticiability of all impeachment challenges is reinforced by the mextricable link between impeachment and the political question doctrime as components of the separation of powers.

14. In recent years, there has been an increasing focus on the justiciability of foreign affairs. See, e.g., JOHN HART ELY, WAR AND RESPONSIBILITY: CONSTITUTIONAL LESSONS of Vietnam and Its AFTermath 55-58 (1993); see THOMAS M. FRANCK, POlitical QUESTIONS/JUdICIAL ANSWERS: DOES THE RULE OF LAW APPLY TO FOREIGN AFFAIRS? (1992) (arguing that foreign affairs should be justiciable); Linda Champlin \& Alan Schwarz, Political Question Doctrine and Allocation of the Foreign Affairs Power, 13 HOFSTRA L. REV. 215, 231 (1985); Redish, supra note 3, at 1052; Michael E. Tigar, Judicial Power, the "Political Question Doctrine," and Foreign Relations, 17 UCLA L. REV. 1135, 1152 (1970); Lawrence R. Velvel, The War in Viet Nam: Unconstitutional, Justiciable, and Jurisdictionally Attackable, 16 KAN. L. REV. 449, 479 (1968). Nevertheless, the nonjusticiability of foreign affairs is more problematic than that of impeachment, because neither the text nor the history of the Constitution makes the former the exclusive donnain of any one branch, and the Franers never discussed the incompatibility of judicial involvement with foreign affairs as they did with inpeachment. 


\section{THE NIXON OPINION}

Walter Nixon, a former federal district judge who was convicted of making false statements before a federal grand jury, sought judicial review of his subsequent removal from office by impeachment. ${ }^{15} \mathrm{He}$ challenged the constitutionahity of the Senate's use of a special committee to receive evidence and take testimony regarding his impeachment rather than conducting a full hearing before the entire Senate. ${ }^{16}$ His essential claim was that the Senate rule authorizing discretionary use of a special trial committee ${ }^{17}$ violated the constitutional command in Article $I$ that the full Senate "try" all impeachments. ${ }^{18}$ His case required the Court to consider for the first time the propriety of judicial review of impeachment proceedings.

Six Justices held Nixon's claim to be nonjusticiable. They found that the word "try" does not represent an "implied limitation on the method by which the Senate might proceed im trying impeachments." In their opinion, that word "lacks sufficient precision to afford any judicially manageable standard of review of the Senate's actions," 20 especially when contrasted with the three "precise" limitations set out in the Impeachment Trial Clause $^{21}$ - that Senate meinbers shall "be on Oath or Affirmation," that the Chief Justice shall preside when the President is tried, and that conviction requires a two-thirds vote of the members present. ${ }^{22}$ Moreover, other language in the same clause giving the Senate the "sole" power to try impeachments was held to constitute a "textual commitment" to a coordinate branch..$^{23}$ Finally, the Court emphasized that judicial review is inappropriate for several reasons: it would upset the Framers' decision to allocate to different fora the power to try impeachments and

\footnotetext{
15. Nixon v. United States, 113 S. Ct. 732, 735 (1993).

16. Id.

17. Senate Comm. on Rules \& Admin., Senate Manual, S. Doc. No. 1, 101st Cong., 1st Sess. 183 (1989) (Senate Impeachment Rule XI).

18. U.S. CONST. art. I, $\S 3$, cl. 6.

19. Nixon, $113 \mathrm{~S}$. Ct. at 736.

20. Id.

21. U.S. CONST. art. I, $\$ 3$, cl. 6.

22. Nixon, $113 \mathrm{~S}$. Ct. at 736 .

23. See id. at $735-36$.
} 
crimes; ${ }^{24}$ it would disturb the system of checks and balances, under which impeachment is the only legislative check on the judiciary;" and it would create a "lack of finality and [a] difficulty [in] fashioning rehef."26

The Court distinguished Powell v. McCormack ${ }^{27}$ on the grounds that it involved a constitutional provision stating that "Each House shall be the Judge of the Elections, Returns, and Qualifications of its own Members," 28 which is limited by Article I, Section 2, which "specifies three requirements for membership in the House: The candidate must be at least 25 years of age, a citizen of the United States for no less than seven years, and an imhabitant of the State he is chosen to represent."29 Hence, "[t]he decision as to whether a member satisfied these qualifications was placed with the House, but the decision as to what [they] consisted of was not." ${ }^{30}$ By contrast, the Impeachment Trial Clause contams no separate provision that "could be defeated by allowing the Senate final authority to determine the meaning of the word "try." "31

Concurring in the judgment, Justice White, jomed by Justice Blackmun, thought the case presented a justiciable question, though in his view of the merits the Senate had "very wide discretion in specifymg impeachment trial procedures," ${ }^{\text {"32 }}$ so that as a practical matter a successful judicial challenge was unlikely. Still, Justice White beheved that proper checks and balances are best preserved when Senate impeachment trials help control the largely unaccountable judiciary, "even as judicial review would ensure that the Senate adhered to a minimal set of procedural standards in conducting impeachment trials." 33 The requirement that the Senate "try" impeachments creates judicially manageable standards, which would be violated "[w]ere the Senate, for example, to adopt the practice of automatically entering a judgment of

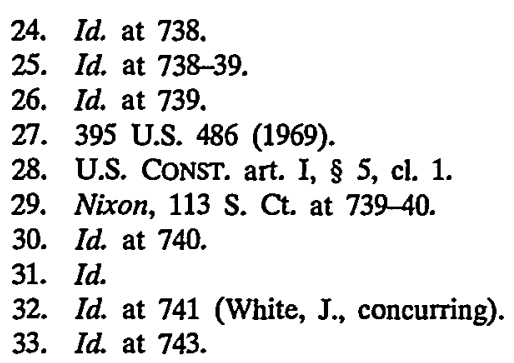


conviction whenever articles of impeachment were dehivered from the House."34

Concurring separately in the judgment, Justice Souter agreed with the Court that the case presented a nonjusticiable political question, but he thought that the determination should be made on a case-by-case basis. If the Senate were to convict upon a coim toss, or upon a summary determination that the official was a "bad guy" (Justice Souter borrowed this example from Justice White), "judicial interference imight well be appropriate." 35

\section{Putting Nixon Into Perspective}

The significance of Nixon is best illustrated by fixing its place in the developinent of the political question doctrine. This analysis demonstrates that Nixon added critical momentum to one side of the long-standing debate on the constitutional authority for judicial recogmition of pohitical questions. This inquiry also sets the stage for assessing Nixon's impact on the justiciability of future impeachment challenges.

\section{A. The Origins of the Political Question Doctrine}

The Court first recognized the concept of a political question in Marbury v. Madison. ${ }^{36}$ In that case, Chief Justice John Marshall explained that the Constitution invests "the president ... with certam important political powers, in the exercise of which he is to use his own discretion, and is accountable only to his country in his political character and to his own conscience. . . . The subjects are political. ... [B]eing intrusted to the executive, the decision of the executive is -onclusive." 37 "Questions in their nature political, or which are, by the constitution and laws, subımitted to the executive, can never be made in this court."38 Chief Justice Marshall contrasted political questions with cases in which individual rights were at stake; the latter, according to the Court, never could be political questions. ${ }^{39}$ Thus, in Chief Justice Mar-

\footnotetext{
34. Id. at 744.

35. Id. at 748 (Souter, J., concurring).

36. 5 U.S. (1 Cranch) 137, 165-67 (1803).

37. Id, at 165 .

38. Id. at 170 .

39. Id.
} 
shall's opinion, the political question doctrine was narrow: it included only matters over which the President had unlimited discretion and with respect to which there was consequently no allegation of a constitutional violation. For example, the Constitution does not constrain the President's clooice about whom to appoint to the federal judiciary.

The ensuing debate over the political question doctrine has reflected a basic contest over the legitimacy and scope of judicial review in a democratic society. Among the more notable figures in this polemic in the twentieth century were Herbert Wechsler and Alexander Bickel. In the late 1950s, Wechsler argued for an unqualified duty of judicial review in every constitutional case. ${ }^{40}$ In his view, the rule of law in this country is coextensive with judicial review, which is imdispensable for the recognition and enforcement of all constitutional limitations and guarantees. He believed federal courts should issue opimions on the constitutional allotments of political discretion and thereby preserve their exclusive function of constitutional interpretation. ${ }^{41}$ As Chief Justice Marshall recognized in Marbury, it is the special "province and duty of the judicial department to say what the law is."42 Thus, for Wechsler, courts had to interpret the impeachment clauses, like all constitutional provisions, to ensure compliance with the Constitution and to effectuate the separation of powers. ${ }^{43}$

In contrast, Bickel contended that the political question doctrine was the culmination of the "passive virtues," the devices that allow a court to decide when not to decide. ${ }^{44} \mathrm{He}$ explained that the legitimate exercise of judicial review in a democracy rests to a significant degree on a court's ability to articulate the "enduring values" of a society. ${ }^{45}$ Thus legitinated, courts perfornning judicial review undertake not just a "checking function" to keep each of the elected branches from abridging individual liberties or making itself stronger at the expense of another branch, but also a "legitimating function," by rallying support for particular legal positions

40. Herbert Wechsler, Toward Neutral Principles of Constitutional Law, 73 HARV. L. REV. 1, 2-3 (1959).

41. Id. at $7-8$.

42. Marbury, 5 U.S. at 177.

43. See Wechsler, supra note 40 , at 8 .

44. Alexander M. Bickel, The least Dangerous Branch: The Supreme COURT AT THE BAR OF POLITICS 183-97 (2d ed. 1986).

45. Id. at 23-27. 
and by symbolizing the power and continuity of the Constitution itself. ${ }^{46}$

Consequently, in Bickel's view, courts must phrase their opmions carefully and know when to stay their hand or remam silent as they wait for principle to ripen im the face of necessary political compromise. ${ }^{47}$ The political question doctrine is just one of a number of "techniques that allow leeway to expediency without abandoning principle." 48 More precisely, the doctrine comprises questions about which we believe "that even though there are apphicable rules, these rules should be only among the numerous relevant considerations. ${ }^{349}$ The possibility of decision on principle exists, but it must yield to the necessity of national security or the limits of political consensus. ${ }^{50}$

At about the same time Bickel published the book in which he made these arguments, the Court decided Baker v. Carr, setting forth the modern test for finding a political question. According to the Court, a pohtical question exists only when a case involves

on the surface ... a textually demonstrable constitutional commitment of the issue to a coordinate political department; or a lack of judicially discoverable and manageable standards for resolving it; or the impossibility of deciding without an initial policy determmation of a kind clearly for nonjudicial discretion; or the impossibility of a court's undertaking independent resolution without expressing lack of the respect due coordinate branches; or an unusual need for unquestioning adherence to a political decision already made; or the potentiality of embarrassment from multifarious pronouncements by various departments on one question. ${ }^{52}$

The Court concluded that "no dismissal for nonjusticiability on the ground of a political question's presence" is appropriate without at least one of these elements. ${ }^{53}$ The Court also conceded, however, that "courts cannot reject as 'no law suit' a bona fide controversy

\footnotetext{
46. Id. at $29-33$.

47. See id. at 70-71.

48. Id. at 71.

49. Id. at 185 (citation omitted).

50. Id. at $186-87$.

51. 369 U.S. 186 (1962).

52. Id. at 217.

53. Id.
} 
as to whether some action denominated 'political' exceeds constitutional authority." 54

The Court's reluctance over the next thirty years to recognize pohitical questions fueled criticisms of the doctrime. First, some critics argued that "the political question doctrine should play no role whatsoever in the exercise of ... judicial review." 55 They contended that the judicial role is to enforce the Constitution, arguing that matters are placed in the Constitution to imsulate them froni majoritarian control and that the pohitical branches should therefore not be trusted to enforce any part of the document meant to constrain them. Instead, im their view, judicial review exists to enforce and effectuate the Constitution.

Second, other critics rejected Bickel's depiction of the fragility of the Court's legitimacy. They maintained that the Court's credibility is resilient, that there is no proof that specific rulings affect the judiciary's legitimacy, and that the federal courts' nission is to uphold the Constitution in spite of any adverse political reaction to its opimons. ${ }^{56}$

Third, some critics argued that the pohtical question doctrine confuses deference with abdication. In their view, the finding of a nonjusticiable political question is a shorthand label for a court's real conclusion that there was no constitutional violation, or that the government defendant did not exceed the bounds of the discretionary authority assigned to it by the Constitution..$^{57}$ For exanple, in an influential 1976 article, Professor Louis Henkin clamed to have discovered a trend in which federal courts' findings of political questions

54. Id.; see also INS v. Chadha, 462 U.S. 919, 942-43 (1983) ("[T] constitutional issues with significant political overtones does not automatically invoke the political question doctrine.").

55. Redish, supra note 3, at 1033; see also ERWIN CHEMERINSKY, INTERPRETING THE CONSTITUTION 99-105 (1987).

56. See CHEMERINSKY, supra note 55, at 133-38. See generally LAURENCE TRIBE, AMERICAN CONSTITUTIONAL LAW 96-107 (2d ed. 1988) (describing the political question doctrine).

57. See Henkin, supra note 1 , at 601, 605-06; see also CHEMERINSKY, supra note 55, at 101-02. Cf. Dellinger, supra note 2, at 397-98, 411 (suggesting that the Court erred in not finding judicial supervision of amendment process warranted); Fritz W. Scharpf, Judicial Review and the Political Question: A Functional Analysis, 75 YALE L.J. 517, 566 (1966) (arguing that no principled explanation exists for the Court's political question cases). 
required no ... extra-ordinary abstention from judicial review; they called only for the ordinary respect by the courts for the pohtical domain. Having reviewed, the Court refused to imvahdate the challenged actions because they were within the constitutional authority of [the] President or Congress.... [It gave] "effect to what the political branches have done because they had political authority under the Constitutiou to do it." 58

Even with regard to "the unique [textual] instance, '[t]he Senate shall have the sole Power to try all Impeachments," Professor Henkm claimed that "while the Senate alone is to be the judge in impeachment proceedimgs, the courts can review how it does it, at least for constitutional excesses or infirmities." 59

\section{B. The Status of the Political Question Doctrine in the Aftermath of Nixon}

In disımissing Nixon's challenge to his renoval as posing a nonjusticiable political question, the Nixon Court rejected the traditional critiques of the political question doctrine..$^{60}$ Even so, nei-

58. Henkin, supra note 1 , at 601 (footnote omitted). In her post-Nixon survey of political question cases, Professor Brown identifies a different trend. She claims that in cases in which the Court has dismissed a challenge on political question grounds, the Court has held

a matter to be nonjusticiable on political-question grounds only where the standing of the claimant, broadly conceived, or the concreteness of the claim can itself be said to be questionable or uncertain. When the standing of the claimant and concreteness of the claimed imjury are not in question, the courts have generally not found adjudication to be precluded by the political-question doctrine.

Brown, supra note 5, at 144-45.

59. Henkin, supra note 1 , at $605 \mathrm{n} .26$. Another criticism of the political question doctrine is that Baker v. Carr does not set forth "useful criteria for deciding what subject matter presents a nonjusticiable political question." CHEMERINSKY, supra note $4, \S 2.6$, at 126. For example, the text of the Constitution does not state that Congress and the President should decide whether a particular action constitutes a constitutional violation. Nor does the Constitution mention judicial review or limit it by creating "textually demonstrable . . . commitment[s]" to other branches of government. Baker v. Carr, 369 U.S. 186, 217 (1962). Similarly, many important constitutional provisions are written in broad, open-textured language and do not entail "judicially discoverable and manageable standards." Id.

60. In the 1991 Term, the Court set the stage for Nixon by rejecting the suggestion that a political question existed when, and only when, there was no constitutional violation. See Department of Commerce v. Montana, 112 S. Ct. 1415 (1992). The Court declared that "[i]n invoking the political question doctrine, a court acknowledges the possibility that a constitutional provision may not be judicially enforceable. Such a decision is of course very different from determining that specific congressional action does not violate the Constitution." Id. at 1425 (footnotes omitted). Nevertheless, the Court in 
ther Nixon nor the doctrine it reaffirmed is immune to attack. In the most significant attack thus far on Nixon, Professor Rebecca Brown argues that the separation of powers exists to protect individual rights, that judicial review is an integral part of the separation of powers, and that the Nixon Court should therefore have "permit[ted] judicial review of the exercise of the impeachment power" to ensure that no individual right was being violated. ${ }^{61}$ The individual right at risk in an impeachment is a federal judge's potential loss of position, including the independence she is otherwise guaranteed by Article III. ${ }^{62}$

Moreover, the Court did not reconcile the apparent irony of its reviewing the contours of an area of political decisionmaking to preserve the area from judicial review in the name of nonjusticiability with its refusal to acknowledge that its deference may have turned on an imphicit judgment that the Constitution simply grants the political actor broad discretion. In addition, the Court's reliance on constitutional and prudential factors ${ }^{63}$ in disınissing Nixon's claim as a "pohtical question" nnay have cast doubt on the legitimacy of the Court's inquiry. The concern is that the political question doctrine nay have enlarged the judiciary's role in deciding constitutional questions because it has allowed courts to use disingenuous analysis to reach certain results or to inake constitutional decisions on a basis not clearly linked to the text, structure, or history of the Constitution. ${ }^{64}$

There are three responses to these problems. First, the Court referred to a finding of "nonjusticiab[ility]"-a constitutionally compelled conclusion barring judgment on a dispute's inerits-as

\footnotetext{
Montana held that the case, which involved the constitutionality of a reapportionment scheme adopted by Congress for the House of Representatives, was justiciable, because it was no different from Baker. Id. at 1425-26.

61. Brown, supra note 5, at 138.

62. Id. at 137.

63. See Nixon v. United States, 113 S. Ct. 732, 735-40 (1993).

64. Judge Raymond Randolph took this position in Nixon's case before the U.S. Court of Appeals for the District of Columbia Circuit. He characterized the political question doctrine as "amorphous" and as

ultimately ... conferring on the courts a rather large role in impeachments although the Framers intentionally excluded the judiciary. ... I view the controlling question as whether the judiciary can pass upon the validity of the Senate's procedural decisions. My conclusion that the courts have no such role to play in the impeachment process ultimately rests on my interpretation of the Constitution.

Nixon v. United States, 938 F.2d 239, 248 (D.C. Cir. 1991) (Randolph, J., concurring) (citation omitted), aff'd, $113 \mathrm{~S}$. Ct. at 732 .
} 
the functional equivalent of discovering a "pohtical question."65 This reference may reflect a strategic decision to preserve a majority committed to avoiding the merits of the case despite widespread criticism of the pohtical question doctrine. Some Justices might not have minded that the political question doctrine was judicially created and allows consideration of the consequences of judicial review, whereas others might have felt more comfortable viewing their inquiry as being guided solely by the Constitution's limits on justiciability. Even so, Nixon emphasized the textual, historical, and structural arguments supporting the Court's finding of nonjusticiability. ${ }^{66}$ The Court also stressed that the term "try" does not offer "an identifiable textual hmit on the authority which is committed to the Senate.".67

The Court found further that prolonged court battles over an impeachment would create uncertainty about its finality and as to "what relief a court may give other tlian simply setting aside the judgment of the conviction. Could it order the reinstatement of a convicted federal judge, or order Congress to create an additional judgeship if the seat had been filled in the interim?"68 Hence, the Court's opimion in Nixon relied on prudential concerns related to the possible consequences of certain constitutional decisions, as well as on arguments based on the text, structure, and history of the Constitution. In other words, Nixon did not bury the political question doctrine; rather, Nixon resuscitated it by clarifying both its derivation from the Constitution and its sensitivity to the need for constitutional stability.

Second, the idea that a federal court may have to exercise some degree of judicial review in order to determine the existence of a political question is hardly a reason to jettison the entire enterprise as deceptive or confusing. In explaining his willingness to reach the merits of Nixon's claml in the U.S. Court of Appeals for the District of Columbia Circuit, Judge Harry Edwards quoted iny observation in 1989 that

65. Nixon, 113 S. Ct. at 735.

66. See id. at $738-40$.

67. Id. at 740 .

68. Id. at 739; see also id. (expressing concerns that hitigation over impeachment could "expose the political hife of the country to months, or perhaps years, of chaos") (quoting Nixon, 938 F.2d at 246). 
[t]he lesson of Powell is that the Supreme Court may use judicial review to determine whether Congress followed the proper procedure for making the political decision committed to it by the Constitution. Powell does not allow overly intrusive judicial review, but rather allows review solely to ensure that Congress made the particular kind of political decision entrusted to it by the Constitution. ${ }^{69}$

Judge Edwards proceeded to find that Nixon's challenge required the appellate court to determine the scope of the term "try" and, therefore, to reach a ruling on the merits of the lawsuit's contentions. $^{70}$ Yet, my statement, admittedly not as clear as it should have been, was meant to support the opposite conclusion. It recognized that $\mathrm{m}$ determining whether a case poses a political question, a court may look to see if Congress is im fact exercising the power it claims to be. If Congress is using inappropriate means to achieve a legitimate objective, then further judicial intervention is permissible. Moreover, in a political question case, a court does not just look at the contours of a particular area of political decisionmaking and decide to defer to any decision made within that sphere because it is constitutional; rather, a court exercises judicial review to determine the scope or boundaries of an area about whose subject matter it should not express any opinion.

Viewed in this manner, the determination of a political question requires a court to make the kmd of decision it must routinely make in adjudicating preliminary issues about the ripeness or mootness of a lawsuit, personal jurisdiction, and standing. The obvious consequence of a finding that none of the essential criteria for a lawsuit to qualify as a case or controversy are present is that a court dismisses the case witlout a decision on the merits, even though in reaching such a conclusion, it must appreciate the nature of the particular dispute and speculate on the applicability of a wide variety of constitutional and prudential concerns. The kind of inquiry required to determine a political question is no less appropriate than any otlier preliminary inquiry undertaken in a federal case to determine tle propriety of adjudicating its merits. ${ }^{71}$

69. Nixon, 938 F.2d at 255 n.6 (Edwards, J., concurring in part and dissenting in part) (quoting Michael J. Gerhardt, The Constitutional Limits to Impeachment and Its Alternatives, 68 TEX. L. REV. 1, 99-100 (1989)).

70. Id. at $255-59$.

71. Professor Brown argues that "[t]he interests [the political question doctrine] might or should serve, such as judicial respect for the processes of the coordinate branches and 
To be sure, the distinction is subtle between reaching the merits of a dispute because it falls within an area over which a court decides that some political actor has extensive constitutional authority and not reviewing the substantive merits of a political actor's decision because it is within a sphere about which a court may not express any opinion. ${ }^{72}$ Nevertheless, a finding of nonjusticiability is not disingenuous, result-oriented, or a substitute for a court's admission of weakness. Such a finding is different from a court's deciding that a wide realm of governmental behavior is constitutional in that a determination of nonjusticiability forecloses a range of potential hitigation and signals once and for all that

efficient use of judicial capital, can be protected adequately by thoughtful adherence to the principles of standing." Brown, supra note 5, at 127. She suggests that in determining whether a particular case actually involves a political question, the Court has relied on standing criteria, "including allegation[s] of injury, causation, and redressability by the courts" and that when these factors were present, the Court had declined to find a political question, until Nixon. Id. at 154; see also supra note 52.

Professor Brown's proposal is problematic for three reasons. First, her determination that the results of the Court's political question cases would not have been any different had the Court used the right analysis, with the possible exception of Nixon, casts doubt on the extent to which her suggestion would clarify the law of either the political question doctrine or standing. Brown, supra note 5, at 154. She suggests that her proposal would make constitutional law more lucid, id. at $126-27$, but the standing doctrine has long been as harshly criticized as the political question doctrine for being easily manipulated and result-oriented. See CFEMERINSKY, supra note 4, § 2.3, at 48-49. Second, she never explains how Nixon would have been decided differently under her notion of the right approach. Near the beginning of her article, she argues that "[t]he Court would have more faithfully effectuated the constitutional design by permitting judicial review of the Senate action, even while perhaps granting substantial deference on the merits." Brown, supra note 5, at 127. At the end of her article, she suggests there was "a clear claim to standing" im Nixon. Id. at 154. Yet, the source of her deference is not clear, especially given the possible involvement of an individual right. Nor does she explain how Nixon might have had standing but still had to lose on the merits. The problem is that it is unclear how her analysis clarifies constitutional law any more than an alternative approach under which one would accept the political question doctrine but find a judicially manageable standard by which to resolve the case. Cf. Nixon, $113 \mathrm{~S}$. Ct. at 743-45 (White, J., concurring) (arguing that the word "try" in U.S. CoNST. art. I, $\S 2$, cl. 6 provides a judicially manageable standard for resolving the case). Third, Professor Brown's approach allows for greater judicial interference with the impeachinent process than the original understanding and structure of the Constitution permit. See infra notes $79-83$ and accoinpanying text.

72. Cf. Nixon, 113 S. Ct. at 741 (White, J., concurring):

It will likely make bittle difference whether the Court's or iny view controls this case. This is so because the Senate has very wide discretion in specifying impeachment trial procedures and because it is extremely unlikely that the Senate would abuse its discretion and insist on a procedure that could not be deemed

a trial by reasonable judges. 
there is no judicial remedy available for any official misconduct within a certain area.

Of course, a federal court needs constitutional authority to dismiss a constitutional case permanently without a ruling on its merits. Accordingly, the third argument favoring the political question doctrine is that the Constitution demands such a result. If the national government in fact is, as Chief Justice Marshall observed in M'Culloch v. Maryland, ${ }^{73}$ one of "enumerated powers,"74 then it should follow that the federal judiciary is, like the other branches, subject to certain constramts, even self-imposed ones. Yet, many of the critics of the political question doctrine seem uncoinfortable with having any branch other than the judiciary declare what the Constitution means; they would prefer that federal judges have the final say on the constitutional limitations of every governmental action. No decision more clearly indicates the fallacy of this notion, however, than Nixon. It recognized that the Constitution limits even federal judicial power. In other words, it may be the special duty of federal courts to "say what the law is,"75 but sometimes the law is that it is miproper for a court to decide the merits of a particular constitutional issue.

Nor does the Constitution necessarily support the notion that it has meaning only as long as the judiciary is einpowered to enforce all of its guarantees or hinits. Judicial review may be necessary to make the enforcement and vindication of various federal rights and limitations possible, but that acknowledgment does not estabhish a constitutional basis for judicial review over every case or controversy imphicating the Constitution.

For example, the constitutional basis for not reaching the merits of Nixon's claim underscores the textual, historical, and structural grounds for a court's finding a political question. As the Nixon Court acknowledged, judicial review over impeachment procedures frustrates the original constitutional scheme in which the Framers foresaw impeachinent as the only political check on the judiciary. ${ }^{76}$ The Court observed further that the parties had not offered "evidence of a single word in the history of the Constitutional Convention or in contemporary commentary that even al-

\footnotetext{
73. 17 U.S. (4 Wheat.) 316 (1819).

74. Id. at 405 .

75. Scharpf, supra note 57 , at 518 .

76. Nixon, 113 S. Ct. at 736.
} 
ludes to the possibility of judicial review in the context of the impeachment powers."77 The Court found this "silence" revealing, because it is at odds with "the several explicit references to the availability of judicial review as a check on the Legislature's power with respect to bills of attainder, ex post facto laws, and statutes." 78

Moreover, the Framers expressed several reasons for excluding any role for federal judges as decisionmakers in the impeachment process. The Framers wanted the body empowered to try impeachments to be sufficiently numerous and to have sufficient fortitude and public accountability to make the necessary policy choices in an impeachment. ${ }^{79}$ The Framers also designed the impeachment process to protect the target of an impeachment from being punished for the same offense twice by preventing judges from being able to administer or oversee both an individual's impeachment trial and separate criminal proceeding. ${ }^{80}$ Moreover, the Framers sought to preclude the "eviscerat[ion]" of impeachment as an "important constitutional check' placed on the Judiciary," which would result from placing the "final reviewing authority with respect to impeachments in the hands of the same body that the impeachment process is ineant to regulate," and to fashion explicit "constitutional safeguards to keep the Senate in check." 82 These protections, including dividing impeachment authority between the House and the Senate and "the two-thirds supermajority vote requirement" for a conviction, are sufficient to prevent the Senate from "usurp[ing] judicial power." ${ }^{83}$ In short, the relevant constitutional text, structure, and history do not support judicial review of the procedural aspects of the constitutionally recognized process for judicial removal.

Thus, an important lesson of Nixon is that constitutional authority does not exist for judicial review of every instance in which there is a constitutional dispute or that the absence of such authority reasonably counsels or supports a finding of nonjusticiabil-

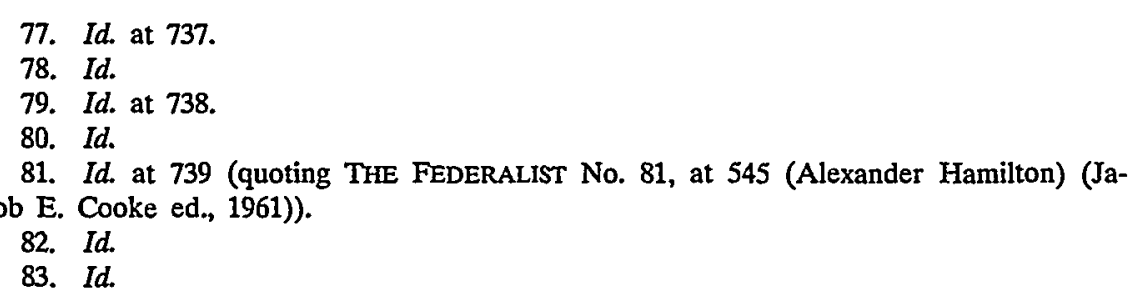


ity. Even so, the next Part considers the potential justiciability of various impeachment cliallenges in light of Powell and Nixon and the subject matter not addressed by those cases.

\section{THE PROSPECTS FOR JUSTICIABLE IMPEACHMENT CHALLENGES IN THE AFTERMATH OF NIXON}

After Nixon, two possibilities exist for judicial review of impeachment challenges. The first is that the only justiciable cliallenges to impeachments are for violations of explicit constraints, while the second is that judicial review is never permissible. I explore below the implications of each prospect.

\section{A. Treating Violations of Explicit Constraints as Justiciable}

One possibility after Nixon is that the only justiciable cliallenges to the impeachment process are for violations of explicit constitutional restraints on impeachment. In Nixon, for example, the Court explained that it exercised judicial review in Powell ${ }^{84}$ to overturn the House's decision not to seat Adain Clayton Powell as a representative based on his financial misconduct, because the House's claim that

its power to [be the judge of its members' qualifications] was a textual commitment of unreviewable authority was defeated by the existence of [a] separate provision specifying the only qualifications which might be imposed for House membership. The decision as to whether a member satisfied these qualifications was placed with the House, but the decision as to what these qualifications consisted of was not. ${ }^{85}$

The Nixon Court held, lowever, that a separate constitutional provision did not defeat the Senate's power to "try" impeachments as it saw fit. ${ }^{86}$ Yet, the Court identified four exphicit constitutional constraints on the impeachment power: the division of impeachment authority between the House and the Senate, the two-thirds vote requirement in the Senate for a conviction, the requirement of the members of the Senate to be under oatl, and the dictate that the Chief Justice shall preside in a presidential impeachment

84. Powell v. McCormack, 395 U.S. 486 (1969).

85. Nixon, 113 S. Ct. at 740.

86. Id. 
trial. ${ }^{87}$ A court looking for the impeachment analogue to the provision enforced in Powell may find justiciable the failure to comply with any of these explicit constraints on the impeachment process, because they each conceivably "defeat[]" the discretion tlie House and the Senate otherwise are constitutionally authorized to exercise in discharging their respective impeachment functions. ${ }^{88}$

If violations of explicit inpeachment restraints are justiciable, it is not difficult to conclude that the four restraints identified by the Nixon majority are indeed justiciable. ${ }^{89}$ Conversely, the hypotheticals of concern to Justices White, Blackmun, and Souter-the Senate's tossing of a coin ${ }^{90}$ and its summary determination that an impeachable official was "a bad guy" - -are conceivably not justiciable. These hypotheticals merely suppose that in the extreme cases the Senate is still exercising soine judgment-albeit poor-in an impeachment proceeding. Even then, the political accountabihty of senators and the three exphicit limitations on Senate proceedings mentioned by the Court act separately and together to make the situations posed in these lypotheticals unhikely and to safeguard against their being undertaken lightly. By holding that "try" does not establislı any judicially "identifiable textual limit"92 on the impeachment process, the Nixon Court did not identify any constitutional basis on which the Court may interfere with the Senate's irresponsible conduct even at the extreine (at least in the absence of a violation of an exphicit command). Moreover, the Court's concerns about preserving the "finality" of impeachment decisions and "fashioning" appropriate "relief" cut against any judicial interference. ${ }^{93}$ Hence, Nixon reveals something significant about the political question doctrine-that it al-

87. See id. at 736,739 .

88. See id. at 740 .

89. See id. at 736, 739. Yet, this simplicity could be illusory. Cf. infra notes 176-91 and accompanying text (arguing that the constraints on impeachment are evidence of its uniqueness).

90. Nixon, 113 S. Ct. at 748 (Souter, J., concurring).

91. Id. at 741 (White, J., concurring).

92. Id. at 740 (majority opinion).

93. Id. at 739. Professor Brown fails to address not only the degree to which either of these factors undercuts her case for judicial review of impeachments but also the fact that her alternative proposal to substitute standing analysis for the political question doctrine acknowledges the propriety of a federal court's deciding to avoid ruling on the merits of a claim because of the difficulties of fashioning appropriate relief. See Brown, supra note 5, at 144. 
lows the Court to stand by silently while the Senate exercises very poor judgment-whereas a holding that would have deferred broadly to the Senate's actions as long as they were reasonable would have allowed judicial review of all impeachments to ensure that the Senate never acted foolislily or recklessly.

The text and the structure of the Constitution may also be read as establishing other impeachment constraints ignored by the Court but still of sufficient clarity that their violations arguably miglit be justiciable. One example is the need for the House to have a majority to impeach. Moreover, the clause limiting the Senate's discretion by allowing it to impose after a conviction only the punishments of removal and disqualification ${ }^{94}$ clearly restrains it from imposing any other sanction, such as confinement or deatli. Similarly, Congress's impeachment autliority is to be exercised only against the President, the Vice President, and "all civil Officers of the United States,"95 obviously precluding the House or Senate from exercising its respective impeachment power over a private citizen who lias never worked a day im government service. ${ }^{96}$

Sometimes, lowever, a constraint is not amenable to judicial enforcement or lias indeterminate justiciable limits. For example, one clieck on the impeachment power is the ballot box, i.e., the political accountability of members of Congress, which is obviously left up to voters ratlier than courts to enforce.

Another constraint is that Congress may impeacl and convict an impeachable official only for committing an impeacliable offense, ${ }^{97}$ sucli that someone could conceivably claim a justiciable violation if lie were convicted and removed from office for beliavior that was well within his legitimate authority and not offensive m any way to the public's trust (sucl as a president's decision to send his child to a private rather tlran a public scliool). But in

94. U.S. CONST. art. I, $\S 3$, cl. 7 ("Judgment in Cases of Impeachment shall not extend further than to removal from Office, and disqualification to hold and enjoy any Office of honor, Trust or Profit under the United States.").

95. Id. art. II, \& 4.

96. See PETER Charles Hoffer \& N.E.H. Hull, IMPEACHMENT IN AMERICA, 1635-1805, at 97 (1984) (suggesting that the delegates to the Constitutional Convention "never wavered" from their agreement to limit impeachment only to officeholders, and therefore to differentiate the federal impeachment process from the English practice under which anyone, except a member of the royal family, could be impeached).

97. U.S. CONST. art. II, $\S 4$ ("The President, Vice President and all civil Officers of the United States, shall be removed from Office on Impeachment for, and Conviction of, Treason, Bribery, or other high Crimes and Misdemeanors."). 
other cases, such as impeaching a federal judge for hiring only white male law clerks, it is difficult to settle on judicially manageable standards, because the existence of an impeachable offense depends inexorably on Congress's pohtical judgment and on the particular circumstances of the alleged impeachable offense involved. ${ }^{98}$ This complication is explored in inore detail in the next Section, because it supports a broader, if not absolute, rule against the justiciability of impeachment challenges, given the concerns about finality, fashioning appropriate relief, and separation of powers that are implicated in any lawsuit cliallenging the impeacl1ment process.

\section{B. The Nonjusticiability of Any Impeachment Challenge}

A second, more extreme reading of Nixon is that no cliallenge to the impeachment process is justiciable. This construction depends on inuch of the same historical and structural understanding that supported Nixon. Indeed, many of the same separation of powers concerns that led the Nixon Court to treat procedural challenges to the Senate's trial process as nonjusticiable would be present in a case involving alleged violations of the explicit constraints on the impeacliment process. For example, the Court in Nixon thrice empliasized that the unique function of the impeachment process as the only legislative check on the judiciary would be "eviscerate[d]" by judicial review. ${ }^{99}$ This threat does not dissipate, at least im the case of judicial review of a judicial impeachment, even if an explicit constraint is involved.

Nevertheless, Professor Brown criticizes Nixon for being based on the erroneous presumption that "judicial review of [impeachment] procedures is equivalent to judicial determination of out-

98. See generally Gerhardt, supra note 69 , at $82-89$ (describing the scope of impeachable offenses).

99. Nixon v. United States, 113 S. Ct. 732, 739 (1993); see id. at 738 (stating that "impeachment was designed to be the only check on the Judicial Branch by the Legislature," such that judicial review of impeachments would be "inconsistent with the Framers' insistence that our system be one of checks and balances"); id. at 739 (observing that judicial review of Nixon's challenge "would eviscerate the 'important constitutional check' placed on the Judiciary by the Framers" and that "Nixon's argument would place final reviewing authority with respect to impeachments in the hands of the same body that the impeachment process is meant to regulate") (citation omitted); id. at $739 \mathrm{n} .2$ (distinguishing Nixon from two other separation of powers cases, neither of which "involved a situation in which judicial review would remove the only check placed on the Judicial Branch by the Framers"). 
come." 100 There are several problems with this critique. It ignores the fact that the effectiveness of impeachment as the only political check on judicial abuse of power is weakened if it can be reviewed by the judiciary. Judicial review of the impeachment process would give judges the last word on the propriety of the procedures for their own removals, and thus the chance to make such removals virtually impossible by demanding that Congress achieve them only through the most complex, time-consuming ways. The risk of self-interested judicial review of judicial impeachments is minimal only if, like Professor Brown, one trusts the judiciary more than Congress not to abuse its respective authority over impeachments. ${ }^{101}$

The problem is that the Framers disagreed. In fact, the Framers believed that the special constraints on the exercise of the impeachment power, such as the political accountability of members of Congress and the division of impeachment authority between the House and the Senate, were meant to be a "complete security" against its abuse. ${ }^{102}$ Moreover, it is significant, given their concerns about the possible conflicts of interest resulting from authorizing different bodies to try impeachments, that the Frainers never mentioned, much less explored, the dilemmas posed by subjecting impeachments to judicial review. ${ }^{103}$

In any event, the same arguments the Framers had for vesting federal impeachment power solely in Congress and not placing it in the federal judiciary led the Nixon Court to treat Nixon's challenges as nonjusticiable ${ }^{104}$ and support forgoing judicial review of any aspects of an impeachment trial. Some of the prudential concerns-particularly "the lack of flnality and the difficulty of fash-

\footnotetext{
100. Brown, supra note 5, at 129.

101. Id. at 138-39.

102. THE FEDERALIST No. 81, supra note 81 , at 545-46.

103. See Nixon, 113 S. Ct. at 737 ; see also BLACK, supra note 13 , at 59,61 : So far as I can find, not one syllable pronounced or written in or around the time of the adoption of the Constitution gives the faintest color to the supposition that the Supreme Court [or the lower courts were] expected to have anything to do with impeachments, or the trial thereof, or appeals thereon. ...

[Nor is there] a shred of affirmative historical evidence that the Framers and ratifiers of the Constitution ever thought for one moment that the lower courts were to deal with impeachment questions. It is quite incredible, given the great amount of attention paid to impeachment procedure, that this possibility never would have been mentioned, if in fact it had been thought a serious possibility.
}

104. See Nixon, 113 S. Ct. at $737-40$. 
ioning relief"-that "counsel[ed] against justiciability" in Nixon ${ }^{105}$ also apply to situations in which explicit impeachment constraints are violated. ${ }^{106}$ Significantly, the Nixon Court used examples from presidential and judicial impeachments to explain how these prudential factors supported a finding of nonjusticiability. ${ }^{107}$

Given the unsettling prospect of an explicit constitutional violation without a judicial remedy, it may be helpful to exannine more closely the degree to which the factors used for identifying a political question support the lack of any judicial review of an impeachment. Of special concern may be the extent to which judicial review is mappropriate in those cases-e.g., presidential impeachments-in which a conflict between the judiciary and the political process constitutionally authorized for its regulation is not present. In such cases, it is particularly interesting that while the text of the Constitution does not clearly support finding explicit violations to be nonjusticiable, constitutional structure and history plainly do.

In fact, Article I states that the House "shall have the sole Power of Inpeachment"108 and that the Senate "shall have the sole Power to Try all Impeachments." ${ }^{\text {"109 }}$ Moreover, the Speech or Debate Clause ${ }^{110}$ has been interpreted to preclude judicial review of the legitimate activities of legislators acting within their official duties, including impeachment. ${ }^{111}$ However, these provisions do not necessarily preclude judicial review, because there may be other judicially enforceable limitations on the impeachment power. ${ }^{112}$

105. Id. at 739 .

106. For two commentaries urging a similar conclusion prior to Nixon, see Gerhardt, supra note 69, at 97-101; Rotunda, supra note 13, at 728-32.

107. See Nixon, 113 S. Ct. at 739.

108. U.S. CoNST. art. I, § 2, cl. 5.

109. Id. § 3, cl. 6 .

110. See id. \& 6, cl. 1:

The Senators and Representatives shall ... in all Cases, except Treason, Felony and Breach of the Peace, be privileged from Arrest during their Attendance at the Session of their respective Houses, and in going to and returning from the same; and for any Speech or Debate in either House, they shall not be questioned in any other Place.

111. See, e.g., Eastland v. United States Servicemen's Fund, 421 U.S. 491, 501-07 (1975); Gravel v. United States, 408 U.S. 606, 624-25 (1972); United States v. Johnson, 383 U.S. 169, 180 (1966); see also In re Request for Access to Grand Jury Materials, 833 F.2d 1438, 1446 (11th Cir. 1987).

112. Nor is the textual support for nonjusticiabihity settled by the provision in U.S. CoNST. art. I, $\S 5$, cl. 2, that "[e]ach House may determine the Rules of its Proceed- 
For example, the Court in Nixon recognized that

the concept of a textual commitment [of an issue] to a coordinate political department is not completely separate from the concept of a lack of judicially discoverable and manageable standards for resolving it; the lack of judicially manageable standards may strengthen the conclusion that there is a textually demonstrable commitment to a coordinate branch. ${ }^{113}$

Applying this principle to Nixon's challenge, the Court determined, after reviewing the general understanding of the term "try" in $1787^{114}$ and its modern usage, ${ }^{115}$ that the word lacks "sufficient precision to afford any judicially inanageable standard of review of the Senate's actions [in an impeachment trial.]"116 The Court found further that this construction was

fortified by the existence of the three very specific requirements that the Constitution does impose on the Senate when trying impeachments: the members must be under oath, a two-thirds vote is required to convict, and the Chief Justice presides when the President is tried. These limitations are quite precise, and their nature suggests that the Framers did not intend to impose additional limitations on the form of the Senate proceedings by the use of the word "try" in the impeacliment trial clause. ${ }^{17}$

Thus, Nixon could be read as treating violations of explicit constraints as presenting judicially discoverable and manageable stan-

ings." As the Court observed over a century ago,

The Constitution empowers each house to determine its rules of proceedings. It may not by its rules ignore constitutional restraints or violate fundamental rights, and there should be a reasonable relation between the mode or method of proceeding established by the rule and the result which is sought to be attamed. But within these limitations all matters of method are open to the determination of the house, and it is no impeachment of the rule to say that some other way would be better, more accurate or even more just. . . . [This rulemaking power is,] within the limitations suggested, absolute and beyond the challenge of any other body or tribunal.

United States v. Ballin, 144 U.S. 1, 5 (1892).

113. Nixon v. United States, 113 S. Ct. 732, 735 (1993).

114. Id. at 736 ("Older dictionaries define try as ' $[\mathrm{t}] \mathrm{o}$ examine' or ' $[\mathrm{t}] \mathrm{o}$ examine as a judge." " (quoting 2 SAMUEL JOHNSON, A DictionaRY OF THE ENGLish LANGUAGE (1785))).

115. Id. ("In more modern usage the term has various meanings. For example, try can mean 'to examine or investigate judicially,' 'to conduct the trial of,' or 'to put to the test by experiment, investigation, or trial.' " (quoting WEBSTER'S THIRD NEW INTERNATIONAL DICTIONARY 2457 (1981))).

116. Id.

117. Id. 
dards of review, unlike the term "try," because those constraints specifically spell out the terms of their enforcement.

Other aspects of the Constitution, however, counsel against the justiciability of explicit constitutional violations in the impeacl1inent context. First, treating impeachments as nonreviewable is consistent with the Constitutional Convention delegates' deliberate decision to exclude any role for the courts im an impeachment, except for providing that the Chief Justice should preside at the impeachment trial of the President. ${ }^{118}$ The Franers also beheved, not insignificantly, that judges inight be influenced by the difficult conflict of interest of impeaching the person who had appointed thein or their fellow judges. ${ }^{119}$ Moreover, the Framers substituted the Chief Justice for the Vice President in the inpeachment trial of a President to preclude the Vice President from presiding over the impeachment trial of the one official standing between him and the presidency. ${ }^{120}$ Given the Framers' efforts to avoid conflicts of imterest in the adiministration of the impeachment process, it is implausible that if the Framers had accepted judicial review of impeachments, they would have failed to comment on the obvious conflicts posed by placing the Chief Justice in the position of being able to participate in the subsequent review of his decisions as the presiding officer of a presidential impeachment trial. Given the strong objections to the proposed impeachment process in the Constitutional Convention and state ratifying conventions, ${ }^{121}$ it is likely that if anyone had expected judicial review of impeachments, he would have objected to or commented on potential conflicts with the Chief Justice's role.

Even as staunch a friend of judicial review as Justice Story ${ }^{122}$ rejected its exercise over impeachments. He explamed

118. See 2 RECORdS OF THE FEDERAL CONVENTION of 1787, at 500, 551 (Max

Farrand ed., 1966).

119. Id. at 398-99.

120. Gerhardt, supra note 69 , at 98 .

121. See BERGER, supra note 13 , at $116-17$.

122. See generally Ronald D. Rotunda \& John E. Nowak, Introduction to JOSEPH STORY, COMMENTARIES ON THE CONSTITUTION OF THE UNITED STATES viii-ix (Ronald

D. Rotunda \& John E. Nowak eds., Carolina Academic Press 1987) (1833):

Story understood that federal courts would be crucial to the enforcement of federal law. Indeed, Story suggested in his scholarly writings and in case dictum that Congress had a constitutional duty to extend the jurisdiction of lower federal courts in a way that would guarantee protection of the supremacy of the federal law. Whenever possible, Story would vote to extend the jurisdiction of federal courts. 
that the Framers viewed Congress as better equipped than the judiciary to deal with the difficult pohtical issues raised in impeachments. ${ }^{123} \mathrm{He}$ noted that the Framers rejected giving the impeachment power to the judiciary because they beheved that impeachment required "a very large discretion [that] must unavoidably be vested in the court of impeachments."124 Justice Story explained further that the Framers understood the power of impeachment as inherently political and therefore vested the power solely with the House of Representatives, "where it should be, im the possession and power of the immediate representatives of the people." $125 \mathrm{He}$ also regarded the sanctions available to the Senate in impeachment trials as "peculiarly fit[ting] for a political tribunal to administer, and as will secure the public agamst political mjuries."126

Second, impeachment decisions are laced with issues incompatible with judicial review. For exainple, the House and the Senate eventually must agree, usually imdependently of each other, on what constitutes an impeachable offense. ${ }^{127}$ The Framers expected that these judgments would be guided not by indictable crimes but rather by amorphous notions of injury to the republic. This expectation is reflected im the references of the delegates at the Constitutional Convention to impeachable offenses as "great" offenses in contrast to indictable ones ${ }^{128}$ and of the delegates at the state ratifying conventions to the propriety of impeaching any official who "deviates from his duty"129 or "dare[s] to abuse the powers vested in him by the people."130

123. STORY, supra note $122, \S 396$, at 280 .

124. Id.

125. Id. $\S 407$, at 290 .

126. $I d$.

127. See Gerhardt, supra note 69 , at 84 (noting that historically impeachment has been understood as a "political proceeding and impeachable offenses as essentially political crimes.").

128. See BERGER, supra note 13, at 88 ("James Iredell, later a Supreme Court Justice, told the North Carolina Convention [during the ratification campaign] that the 'occasion for its exercise [impeachment] will arise from acts of great injury to the community.'" (citation omitted) (second alteration in original)).

129. 4 The Debates in tHe Several State Conventions on the Adoption of THE FEDERAL CONSTITUTION 47 (Jonathan Elliot ed., 2d ed. 1836) (quoting William Maclaine of North Carolma).

130. 2 id. at 169 (quoting Samuel Stillman of Massachusetts). 
Alexander Hamilton echoed such sentiments in The Federalist, observing that

[t]he subjects of [Senate] jurisdiction [in an impeachment trial] are those offenses which proceed from the misconduct of public men, or in other words from the abuse or violation of some public trust. They are of a nature which may with peculiar propriety be denominated POLITICAL, as they relate chiefly to injuries done immediately to the society itself. ${ }^{131}$

James Wilson, who served as a delegate to the Constitutional Convention and to the Permsylvania ratifying convention and later as a Supreme Court Justice, agreed that impeachable offenses covered "pohtical crimes." ${ }^{132}$ Similarly, as Justice Story observed, impeachable offenses are "purely of a political nature"133 and defy classification by statute. No statutes or common law sets forth the impeachable offenses that courts may interpret or apply. Hamilton viewed this circumstance as precluding strict rules of the sort courts commonly apply and requiring imstead a large, politically accountable body to exercise the "awful discretion" necessary for formulating impeachable offenses. ${ }^{134}$ Thus, there are no rehiable or clear standards against which a federal court can measure the propriety of Congress's judgment on whether certam misconduct constitutes an impeachable pohtical crime.

Third, as the Nixon Court acknowledged, ${ }^{135}$ judicial review of impeachments undermines their finality. Judicial review might also lead to embarrassing conflicts between the Congress and the federal judiciary. Allowing the Chief Justice to participate in the judicial review of a President's impeachment trial over which the Chief Justice had presided would obviously be awkward. More importantly, it would be confusing and embarrassing and risk serious pohtical imstability at home and abroad if the Senate voted to

131. The Federalist No. 65, at 439 (Alexander Hamilton) (Jacob E. Cooke ed., 1961).

132. 1 JAMES WILSON, Of the Constitutions of the United States and of Pennsylvaniaof the Legislative Department, in THE WORKS OF JAMES WILSON 399, 426 (Robert G. McCloskey ed., The Belknap Press of Harvard Press of Harvard University Press, 1967) (1804).

133. STORY, supra note $122, \S 406$, at 289.

134. THE FEDERALIST No. 65 , supra note 131 , at 441 .

135. Nixon v. United States, 113 S. Ct. 732, 739 (1993). 
remove the President and then a federal court countermanded that judgment. ${ }^{136}$

Yet, completely precluding judicial review because of these consequences seemingly conflicts with Powell. After all, Powell suggested, as the Nixon Court noted, ${ }^{137}$ that when a constitutional provision plainly restricts the discretion of another branch, a court may imtervene to enforce compliance. ${ }^{138}$ Powell did not involve what the Nixon Court recognized as "a situation in which judicial review would remove the only check placed on the Judicial Branch by the Framers." ${ }^{139}$ Of course, judicial review of presidential imipeachments does not pose a similar conflict, because as a group, judges are not likely to have much, if any, vested interest in the President's remaining in office. Nevertheless, some judges may feel loyal to the President because he appointed them. In short, Powell did not deal with the propriety of judicial review of a power the Framers chose not to give to the judiciary because they felt judges could not be trusted with it.

Yet another basis on which to distinguish Powell, either apart from or in addition to the uniqueness of impeachment, is that Powell has not been properly understood. One could argue that the real problein for the House in Powell was that none of its existing powers for discipliming current or prospective members fit Powell's alleged financial improprieties. The House's expulsion authority required a representative to have been seated and the concurrence of at least two-thirds of the House, ${ }^{140}$ however, many members were not sure if an expulsion could be based on misconduct committed during a prior Congress, as would have been the case for Powell's infractions, and even if the House had such power, they were not sure they had the requisite number of votes. $^{141}$ The other alternative-and the one chosen by the House-was to exclude Powell, but this authority turned on Powell's not having met the three standing qualifications for House membership. Although more than two-thirds of the House voted to exclude Powell, they did so only pursuant to a vote on exclusion. The Court refused to assume that the vote would have

136. See id.

137. Id. at 740 .

138. Powell v. McCormack, 395 U.S. 486, 521 (1969).

139. Nixon, 113 S. Ct. at 739 n.2.

140. U.S. CONST. art. I, § 5.

141. See Powell, 395 U.S. at 508-12. 
been the same if it had been on the question of expulsion, which the Court noted was not a "fungible proceeding[]" with exclusion. ${ }^{142}$ Because the House chose to exercise its exclusion rather than its expulsion power, the Court declined to express any "view on what limitations may exist on Congress' power to expel or otherwise punish a member once he has been seated."143 In his concurrence, Justice Douglas speculated that

if this were an expulsion case I would think that no justiciable controversy would be presented, the vote of the House being two-thirds or more. But it is not an expulsion case. Whether it could have been won as an expulsion case, no one knows. . . . It well might be easier to bar admission than to expel one already seated. ${ }^{144}$

In short, the House faced a no-win situation in trying to punish Powell because his alleged misconduct fell outside of the existing House disciplinary mechanisnis.

This understanding of Powell could lead one to argue, as I have previously, that the Court there

could [probably] not have interfered with the decision by [the House] to expel Representative Powell if [it] had followed the constitutional standards for expulsion; however, the Court could step in where Congress used a procedure to accomplish impermissible ends. Powell indicates that while [the House] has full, complete, and sole power to exclude, it does not have the power to change expulsion into exclusion-to turn one constitutional procedure into another. ${ }^{145}$

Given this understanding of Powell, judicial review of impeachments would be hmited to determining whether the House or the Senate used impeachment to do soinething that it could do only under sonie other power, such as exclusion or expulsion. ${ }^{146}$

142. Id. at 512 .

143. Id. at 507 n.27.

144. Id. at 553 (Douglas, J., concurring).

145. Gerhardt, supra note 69 , at 100 (citations omitted).

146. One could go further to argue that the Court in Powell was mistaken in its conclusion that "the qualifications for members of Congress had been fixed in the Constitution." Powell, 395 U.S. at 540. One could contend that these qualifications are fixed only as to the House but not as to the states or that they constitute only an irreducible minimum to which the House, Congress, or the states each could make an addition, if it chose to do so. See Robert C. DeCarli, Note, The Constitutionality of State-Enacted Term Limits Under the Qualification Clauses, 71 TEX. L. REv. 865, 866 (1993). 
One problem with the latter reading of Powell, though, is that it does not preclude judicial review of impeachments altogether. It preserves judicial review for what would be extremely unlikely abuses of the impeachment power, but it implicitly accepts that all congressional powers have judicially enforceable limits, at least at the point at which one power is being improperly substituted for or being exercised in the place of another. Powell arguably followed this hine of reasoning by suggesting that exclusion and expulsion could be used by the House for different purposes and that the bases for the House's exclusion of Powell did not fit within the scope of that particular power.

For many, an even more serious problem with an attempt to preclude all judicial review of impeachments is that it seems unhikely that the Court ever would agree to abdicate an entire area of constitutional law to another branch. This is especially true with respect to checks and balances; in almost every other situation in which the Constitution allows one branch to check another's excesses or abuses, the Court has taken the position as a mediator, albeit sometimes with very limited authority. For example, the Court has never characterized congressional control of federal jurisdiction as involving a political question. Moreover, some of the areas im which the Court has found a pohitical question, such as determining the appropriate time period for ratification of a constitutional amendment ${ }^{147}$ or whether a state government is repubhican in form, ${ }^{148}$ are not as subject (at least as clearly) as the impeachment power to defeat by other plainly applicable clauses, such as the requirement of a supermajority vote for a conviction. Even in other areas often treated by scholars as comprising or involving nonjusticiable political questions, such as foreign affairs, the Constitution either provides no clear standards by which to measure the propriety of a branch's political judgment (such as whether the situation declared to be a war by Congress was one) or exphcitly provides for the involvement of more than one branch, which has in the past given rise to confusion among the political branches as to whose authority should govern and the need for the Court to act as arbiter. ${ }^{149}$

147. See Coleman v. Miller, 307 U.S. 433 (1939).

148. See Pacific Tel. Co. v. Oregon, 223 U.S. 118 (1912); Luther v. Borden, 48 U.S. (7 How.) 1 (1849).

149. See, e.g., Japan Whaling Ass'n v. Baldridge, 478 U.S. 221 (1986) (declining to 
There are two tenable responses to the reluctance to abandon any judicial review of impeachments. First, the Court has yet to find an impeachment challenge to be justiciable. Regardless of what one thinks is the need for judicial review of impeachment challenges, the Court has never sanctioned it. Thus, as a practical matter, the Court has left the federal impeachment process for over two centuries to the complete, unreviewable discretion of the Congress.

Second, the most worrisome kinds of impeachment abuses have yet to occur. Even if one were inclined to find the need for judicial review of impeachment challenges in extreme cases, the likelihood of such controversies ever arising is, for all practical purposes, nonexistent. If one were truly interested in knowing what Congress is likely to do with its impeachment autliority in the absence of judicial review, one need look no further than the pages of history. They do not contain any of the nightmarish episodes imagined by proponents of judicial review of the impeachment process. Moreover, many of the constitutional restraints on Congress's impeachment authority are self-defining, such as the supermajority vote for conviction in the Senate, sucl that it is easy for tlie Senate to know what it must do at a minimum in order to convict an impeaclied official and avoid obvious controversy.

\section{The Range of Nonjusticiable IMPEAChMENT CHALLENGES AFTER NIXON}

This Part addresses three inatters arguably involving justiciable impeachment challenges that are likely to arise in the future. Each claim implicates the significance of the Constitution's allocation of unique impeachment authority to Congress. The first involves the question of whether the Fiftli Amendinent Due Process Clause ${ }^{150}$

hold nonjusticiable a question of statutory interpretation in a statute passed to implement part of an agreement between Japan and the United States); Dames \& Moore v. Regan, 453 U.S. 654 (1981) (reaching merits of dispute over legality of President Carter's executive agreement for the release of United States hostages in Iran); Youngstown Sheet \& Tube Co. v. Sawyer, 343 U.S. 579 (1952) (invalidating President Truman's seizure of the nation's steel mills despite his claim that national emergency justified the seizure); United States v. Curtiss-Wright Export Corp., 299 U.S. 304 (1936) (reaching merits of congressional delegation of power to the President to prohibit sale of arms to countries engaged in armed conflicts).

150. The Fifth Amendment Due Process Clause provides in pertinent part: "No person shall . . . be deprived of life, liberty, or property, without due process of law . . . " 
applies to the impeachment process, and if so, whether its violation is justiciable. The second is whether the Senate's adoption and subsequent failure to comply with express rules of evidence or a uniform burden of proof for impeachment trials is justiciable. The third is whether a presidential impeachment trial presents a special case requiring judicial review of any procedural irregularities.

\section{A. The Justiciability of Impeachment Challenges Based on Argu- able Violations of the Fifth Amendment Due Process Clause}

Although the Senate followed the same procedures in removing Alcee Hastings from a federal district judgeship as it did in removing Nixon, Hastings challenged his removal froin office in part on the grounds that the Senate's failure to conduct his entire hearing before the full body of the Senate violated the Fifth Amendinent Due Process Clause. ${ }^{151}$ Simply put, his argument was that he had a property interest in keeping his judgeship and salary and that the government could not deprive him of these in an impeachment trial without due process, i.e., without following the proper procedures, including a complete trial before the full Senate. ${ }^{152}$

To be sure, Nixon did not consider this issue because Nixon did not raise it. One could argue that the only justiciable challenges to the impeachment process are for violations of explicit constramts, and inight disagree over the applicability of the Due Process Clause to impeachment, but might concur that if the Clause properly applied, then its violation would be justiciable. Those reading Nixon as indicating that no impeachment challenge is justiciable would argue that even if the Due Process Clause ap-

\footnotetext{
U.S. CONST. amend. V.

151. See Hastings v. United States, 802 F. Supp. 490, 504-05 (D.D.C. 1992) (holding Hastings's impeachment trial unconstitutional because, inter alia, it violated Fifth Amendment Due Process Clause), vacated, 988 F.2d 1280 (D.C. Cir. 1993) (full opinion unpublished), available at 1993 U.S. App. LEXIS 11592 (remanding case for reconsideration in light of Nixon). On remand, the district court reluctantly dismissed the case without explicitly readdressing the due process claim. Hastings v. United States, 837 F. Supp. 3, 5 (D.D.C. 1993) ("As strongly as this Court believes that Judge Hastings' fundamental rights were violated, the Court recognizes that the Nixon decision compels that Judge Hastings' case be dismissed."). But see BERGER, supra note 13, at 120-21 (defending applicability of Fifth Amendment Due Process Clause to impeachment process).

152. Hastings v. United States Senate, Impeachment Trial Comm., 716 F. Supp. 38, 39-41 (D.D.C. 1989).
} 
plied to impeachments, any violation of it would not be justiciable. The latter argument is bolstered by the Court's observation in Nixon that "opening the door of judicial review to the procedures used by the Senate in trying impeachments would 'expose the political life of the country to months, or perhaps years, of chaos." "153 Even so, the central question remains about the applicability and justiciability of the Fifth Amendment Due Process Clause in the impeachinent context.

In spite of what appears to be the plain meaning of the Fifth Amendment Due Process Clause, its application to impeachments is unclear. For one thing, its language, upon further inspection, is not so plainly applicable to the unique context of an impeachnient. The Clause exphicitly provides that no "person" shall be deprived of hife, liberty, or property without due process of law, whereas the impeachment process expressly concerns only the President, the Vice President, and "Officers of the United States." 154 The primary purpose of the Fifth Amendment Due Process Clause was to guarantee procedural protections for private citizens against coercive, arbitrary governmental action. ${ }^{155}$ In contrast, the impeachment process is not directed at government actors in their private capacities.

Although the Supreme Court has held that the Clause requires certain procedural protections in limited circumstances against the arbitrary dismissal of low-level governmental employees, ${ }^{156}$ impeachment is directed at a different class of higher-level governmental officials. An impeachment proceeding is a unique forum in which Congress nuay denrand a public accounting of the misbehavior of one of an elite set of officials. The question in

153. Nixon v. United States, 113 S. Ct. 732, 739 (1993) (quoting Nixon v. United States, 938 F.2d 239, 246 (D.C. Cir. 1991)).

154. U.S. CONST. art. II, \& 4.

155. See Leonard G. Ratner, The Function of the Due Process Clause, 116 U. PA. L. REv. 1048, 1068-69 (1968). See generally NowAK \& RoTUNDA, supra uote 12, § 13.2 (describing judicial construction of "Life, Liberty or Property"); Charles E. Shattuck, The True Meaning of the Term "Liberty" in Those Clauses in the Federal and State Constitutions Which Protect "Life, Liberty, and Property," 4 HARv. L. REV. 365 (1891) (discussing origins and meaning of due process clauses of state and federal constitutions).

156. See NowAK \& RotunDA, supra note $12, \S 13.4$, at 510 (suggesting that "if in dismissing the employee, the government also forecloses the individual's possible employment in a wide range of activities in both the public and private sectors, this dismissal will constitute a deprivation of liberty sufficient to require that the individual be granted a fair hearing"). 
such a proceeding is whether an impeachable officer is fit to preserve the public trust and therefore to reinain in office. In other words, impeachment is a special disciplimary mechanism for special officials. The specific procedural protections given to the subjects of an impeachment are spelled out in the Constitution, including the division of impeachment authority between the House and the Senate and the requirements that senators act under oath, that the Chief Justice preside in presidential impeachment trials, and that at least two-thirds of the senators present agree in order to convict. ${ }^{157}$ Treating impeachments as sui generis is consistent with the absence of any evidence that the Fifth Amendment, including the Due Process Clause, was ever intended to apply to the impeachment process. ${ }^{158}$

The argument against applying the Fifth Amendinent Due Process Clause to impeachinent proceedings, however, seems forced. By its plain terms, the Fifth Ainendinent Due Process Clause forbids Congress froin depriving a "person" of "life, liberty, or property without due process of law;" it is not a stretch to think that the impeachment process, which seeks to deprive someone of his current and perhaps future office, could easily constitute a form of property. Moreover, the fact that the Fifth Amendment postdates the impeachment clauses makes irrelevant any of the Franers' or ratifiers' original desires regarding the federal impeachment process. The point of an ainendment is to change what came before and that could logically cover the impeachinent process no matter how special it was conceived to be.

Even if the Fifth Amendinent Due Process Clause applied to the impeachment context, though, it is not likely that it would inandate anything different froin the procedures otherwise required. The arguinent supporting application of the Due Process Clause to the impeachment process maintains in part that a federal judge has a property interest in his position. Yet, a property interest for purposes of the Due Process Clause is defined as an entitleinent or expectation based on federal law. ${ }^{159}$ For exainple, a

157. U.S. CONST. art. I, § 3, cl. 6.

158. Nor is there any reason to suppose that the different procedural guarantees of the Fifth Amendment, such as the prohibition against self-incrimination should be treated differently for purposes of determining their applicability to the impeachment process. Consequently, the argument against applying the Due Process Clause to the impeachment process also precludes applying any of the other procedural guarantees of the Fifth Amendment to impeachment trials.

159. Board of Regents v. Roth, 408 U.S. 564, 577 (1972); see NowAK \& RoTUNDA, 
federal judge assumes office under the conditions for removal as spelled out in the Constitution. ${ }^{160}$ In other words, a federal judge has life tenure unless and until he is removed from office in a constitutionally permissible manner, including impeachment under the special procedures spelled out in the text. ${ }^{161}$ Thus, the Impeachinent Trial Clause conceivably clarifies the reach of the Due Process Clause, in spite of the latter's subsequent enactunent, because the former arguably defines what process is due in a judicial removal.

It is also not likely that the Due Process Clause would constrain the Senate's discretion to conduct impeachment trials any more than does the term "try." The Nixon Court observed, for example, that the fact that the Framers set out specific limitations applicable only to impeachments confirms "that the Framers did not intend to impose additional limitations on the form of the Senate proceedings by the use of the word "try." $" 162$ The point is that where the Framers wanted to ensure specific constraints on the procedure used by the Senate for trying impeachments, they spelled them out in the Constitution. The process that is due in an impeachinent trial consists of the explicit constitutional requirements set forth in the document. Otherwise, the Senate has nonreviewable discretion to conduct its hearings as it prefers. There is no evidence to suggest that at the time the Constitution was amended to include the Bill of Rights, the Framers intended either to revise their prior position of spelling out explicitly in the text the required procedures for impeachments or to add any other specific procedural requirements for impeachments to those set forth in the original Constitution. ${ }^{163}$ Thus, the Due Process Clause does not constrain congressional discretion any more or differently than does the Inpeachment Trial Clause.

\footnotetext{
supra note $12, \S 13.5$, at $513-16$.

160. U.S. CONST. art. III, $\S 1$.

161. Id. art. II, § 4. See generally Peter M. Shane, Who May Discipline or Remove Federal Judges? A Constitutional Analysis, 142 U. PA. L. REV. 209, 215-22 (1993) (describing the Framers' rejection of political removal mechanisms other than impeachment and describing judicial self-regulation).

162. Nixon v. United States, 113 S. Ct. 732, 736 (1993).

163. See Arthur Bestor, Impeachment, 49 WASH. L. REV. 255, 268 (1973) (reviewing BERGER, supra note 13).
} 
B. The Justiciability of Challenges to the Senate's Failure to Follow Rules of Evidence or a Uniform Burden of Proof

Another difficulty left unanswered by Nixon is whether the Senate's adoption of and subsequent failure to comply with specific rules of evidence or a uniform burden of proof for impeachment trials is justiciable. This problem raises two interrelated questions: (1) whether the Senate has the power to tie its hands im this manner, and if so, (2) whether such conduct on the part of the Senate amounts to a waiver of the insulation or immunity from judicial review its procedural decisions otherwise enjoy to the extent recognized in Nixon. Each of these issues in turn raises special concerns.

There are, in fact, two practical problems with the Senate's ability to bind each imdividual senator in an impeachment trial to follow certain rules of evidence or a uniform burden of proof. First, to the extent that such uniform standards deprive any senators from reaching the kind of final judgments they prefer in an impeachment trial, they may undermine the constitutional requirement of a supermajority of at least two-thirds of the Senate concurring in order to convict. This restriction sought to protect the subjects of impeachment trials from capricious abuse of impeachment authority and from the tyranny of a partisan majority; it guaranteed that convictions could occur only if a significant minority of senators did not object. ${ }^{164}$ Any rule adopted by a majority of the Senate that frustrates the constitutionally authorized ability of a minority-i.e., one-third-of the Senate to defeat an impeachment conviction is suspect. An attempt by the majority of the Senate, through the adoption of set evidentiary rules or a burden of proof, to deprive individual senators of the power that normally belongs to a third of the body im impeachment trials to bar convictions likely would be unconstitutional.

Second, although a majority of the Senate has the formal power to change the procedural rules for an impeachment tri$\mathrm{al}^{165}$ the Senate traditionally permits the implementation of changes in its procedural rules only if it has unanimous consent to do so. $^{166}$ The significance of this practice is that it is incon-

164. See HoFFer \& HULL, supra note 96 , at 102-06.

165. S. Res. 479, 99th Cong., 2d Sess. (1986) (enacted).

166. As one commentator has noted, 
ceivable that the full Senate ever would agree to adopt a uniform standard of proof or set rules of evidence. Indeed, a basic principle recognized in every impeachment trial conducted thus far is that each senator must ultimately decide for himself on which rules of evidence or burden of proof to apply. ${ }^{167}$ Moreover, it is difficult to conceive how such uniform standards could ever be enforced. In recognition of this impossibility, the National Commission on Judicial Discipline and Removal decided to forgo recommending that the Senate adopt a uniform burden of proof. ${ }^{168}$

The Commission did recommend, however, that the Senate adopt set rules of evidence. ${ }^{169}$ If the Senate ever succeeded in modifyiug its impeachment rules and practices to require the apphcation of uniform rules of evidence (or, for that inatter, a set burden of proof) in impeachinent trials, the critical question would be whether such an action would constitute a waiver of the Senate's immunity from judicial review as recognized in Nixon. The settlement of this issue depends on whether the Senate has the power to waive its constitutional immunity from judicial review.

On the one hand, several factors argue agamst the existence of such power. These imclude the Framers' distrust of judges and consequent decision-changeable only by constitutional anendnient-to exclude thein as decisionmakers in the impeachment process; ${ }^{170}$ the weakening of inıpeachment as a check against executive and especially judicial abuse of power; the conflicts of interest judges would have in overseeing the only constitutionally recognized process for their removal; and the difficulties judicial review would pose with respect to finality and fashioming appropriate rehef.

On the other hand, in the context of adninistrative law, the Supreme Court has declared that "judicial review of a final agency action by an aggrieved person will not be cut off unless there is

Both houses also have the option of setting aside particular rules, or creating entirely new ones, by unanimous consent. This device is especially popular in the Senate, where standing rules and precedents exist to control the practice. Of course, even those rules can always be set aside by unanimous consent.

Michael B. Miller, Comment, The Justiciability of Legislative Rules and the "Political" Political Question Doctrine, 78 CAL. L. REV. 1341, 1345 (1990) (citations omitted).

167. See NATIONAL COMM'N ON JUdicial Discipline \& REMOVAL, REPORT OF THE National Commission on Judicial Discipline AND Removal 60 (1993).

168. Id.

169. Id. at 57.

170. See supra notes $80-82$ and accompanying text. 
persuasive reason to believe that such was the purpose of Congress." 171 In other words, if a lawmaking body or administrative agency were really interested in barring judicial review of certain actions or proceedings, it may do so only if it issues a "clear statement" of that wish. ${ }^{172}$ Under these circumstances, courts ask for a "clear statement" because they want to be sure about precisely how much power Congress has delegated to some politically unaccountable body. If the Senate's adoption of evidentiary or burden of proof rules were construed as the functional equivalent of a legislative or administrative act undertaken for the purpose of giving up some of the Senate's discretion in impeachment trials, then waiving nonjusticiability in the impeachment context might be possible only if there were a "clear statement" to that effect. ${ }^{173}$

At least one advantage of allowing the Senate to waive nonjusticiability (or to presume nonjusticiability unless there is some

171. ' Abbott Labs. v. Gardner, 387 U.S. 136, 140 (1967). The Court further stated that "only upon a showing of 'clear and convincing evidence' of a contrary legislative intent should the courts restrict access to judicial review." Id. at 141; see also Citizens to Preserve Overton Park v. Volpe, 401 U.S. 402,410 (1971).

172. See William N. Eskridge, Jr., \& Philip P. Frickey, Quasi-Constitutional Law: Clear Statement Rules as Constitutional Lawmaking, 45 VAND. L. REV. 593, 597 (1992) ("Judicial review does not prevent the Congress from legislating, but judicial interpretation of the resulting legislation requires an extraordinarily specific statement on the face of the statute for Congress to limit the states or the executive department."). The number of areas in which the Burger and Rehnquist Courts have required Congress to issue "clear statements" if it intends to displace "structural constitutional protections, especially those of federalism," is widespread. Id. For example, in Atascadero State Hospital v. Scanlon, 473 U.S. 234, 242 (1985), the Court concluded that "Congress may abrogate the States' constitutionally secured immunity from suit in federal court [by virtue of the Eleventh Amendment] only by making its intention unmistakably clear in the language of the statute."

173. In Webster v. Doe, 486 U.S. 592 (1988), the Supreme Court recognized a significant exception to this rule. The Court held that the decision of the Central Intelligence Agency to discharge an employee was so committed to agency discretion as to preclude judicial review, except for serious constitutional questions. Id. at 601. The Court based its holding in part on a tradition of treating the hiring or firing of employees as being within an agency's nonreviewable discretion and on there thus being "no law to apply"-i.e., no legislative or other kind of judicially cognizable legal standard to restrict the agency's discretion. Id. at 599 (quoting Citizens to Preserve Overton Park, 401 U.S. at 410). In dissent, Justice Scalia went further to find constitutional questions precluded as well. Id. at 608-09 (Scalia, J., dissenting). If tradition and separation of powers concerns led the Court in Webster to bar judicial review of an agency decision, it is possible that similar factors could lead the Court to bar judicial review of an impeachment proceeding in spite of the Senate's failure to comply with certain procedural rules or to allow judicial review only if the Senate waived nonjusticiability by issuing a clear statement of its desire to do so. 
clear statement to the contrary) is to make it easier for it to use set evidentiary rules or a uniform burden of proof by not treating either as legally binding in that noncompliance would not justify legal sanctions. Such deference seems particularly appropriate in the impeachment context, in which the adoption of set procedures for impeachment trials is likely to work to the advantage of all the participants by providing predictable and consistent practices or standards. Moreover, judicial deference makes sense in light of the Nixon Court's reasonable concerns that "opening the door of judicial review" to impeachments is likely to produce uncertainty as to the "finality" of impeachment decisions ${ }^{174}$ and potentially intractable problems of "fashioning [appropriate] relief." 175

Obviously, a lot turns on which presumption of judicial review is appropriate in this context. One possible view is that because judicial review of impeachment trials normally is thought not to be permissible, it should be presuned impermissible unless the Senate issues a clear statement of its intent to subject its compliance with certain procedural rules to judicial review. Another approach suggests that impeachment proceedings are usually nonjusticiable, unless they violate express constitutional limits. In other words, if violations of express constraints are justiciable, the question is whether set evidentiary rules or a uniform burden of proof constitute such himits, and if so, are similarly justiciable. One simple way to resolve this conundrum would be for the Senate, at the appropriate time, to state clearly its intent to retain or to preclude judicial review-whichever it prefers-of its compliance with set evidentiary rules or a uniform burden of proof.

\section{The Nonjusticiability of Challenges to Deficiencies in Presiden- tial Impeachments}

A presidential impeachment trial poses inany of the same problems encountered in judicial impeachments as well as offering

174. Nixon v. United States, 113 S. Ct. 732, 739 (1993). For example, it is safe to say that the political turmoil likely to result in the interim in which a President is contesting his removal would probably not be affected by the Senate's decision to adopt or forgo set rules of evidence or a uniform standard of proof.

175. Id. Even if it could be established that there were violations of set rules of evidence or a uniform burden of proof, it is unclear, as the Nixon Court recognized, what a court could legitimately order "other than simply setting aside the judgment of conviction." Id. For example, it is not even clear whether a harmless error rule would apply. 
more dramatic illustrations of the constitutional foundations for precluding judicial review of the federal impeachment process. I explore below the problems with judicial review of any aspect of a presidential impeachment trial.

1. The Difficulty of Devising Proper Judicial Remedies. Sometimes it is difficult to devise a judicial remedy for a violation of an exphicit constraint. For example, the Constitution provides that "[w]hen the President of the United States is tried, the Chief Justice shall preside."176 At first glance, the Chief Justice's failure to preside over a President's impeachment trial is a constitutional violation, which arguably may justify judicial review in a way similar to the Court's imtervention in Powell to ensure that an explicit textual constraint has not been ignored.

Yet, the situation is more complex than it seems. Imagine further that before the President's impeachment trial is about to begin, the Chief Justice dies or claims a conflict of interest precluding his participation; or, after the trial begins, the Chief Justice refuses to participate further to protest what he views as an unconstitutional Senate procedure. ${ }^{177}$ It is unlikely that the Senate would delay the President's impeachment trial so that it could consider confirmation of a person he has appointed as Chief Justice, who would then preside over his impeachment trial. Thus, it is quite probable that there would be no Chief Justice to preside over the presidential impeachment trial.

Under such circumstances, one could argue that the provision mandating that the Chief Justice preside over a presidential impeachment trial has been violated but that the violation is meaningless, if, for example, the most senior Associate Justice were to preside instead. Judicial review seems pointless here, because it would lead to outrageous results, compounded by further delays in the impeachment trial, causing substantial domestic and foreign confusion over who should be President of the United States. For example, the courts might order the Senate to schedule a confirmation hearing on a matter it seems to have the constitutional

176. U.S. CONST. art. I, § 3, cl. 6.

177. One could suppose, for example, that the Senate designates a special committee . to do factfinding for a presidential impeachment trial and asks the Chief Justice to preside over that committee's proceedings. The Chief Justice may declare the trial committee's proceedings unconstitutional, and if overruled by the Senate, refuse to participate further, perhaps pending interlocutory appeal. 
prerogative to plan as it sees fit, or it might order the President to appoint a Chief Justice that the Senate sooner or later would have to confirm (if it wanted to move forward) when it might be in the President's interest to delay the appointment as long as possible. These judicial orders would involve the courts in making or directing policy choices committed by the Constitution to political actors, and they are not as hikely to preserve constitutional stability as to allow Congress and the President work out a mutually satisfactory settlement.

2. The Omnipresent Need for Finality, Especially in Presidential Impeachments. If the Senate were to use a special committee to do factfinding for a presidential impeachment trial, there would be two conceivable arguments supporting justiciability. The first is that the President is entitled to a trial before the full Senate because of the clause stating that the Chief Justice "shall preside" at his impeachment trial. ${ }^{178}$ This is a dubious basis to justify a full trial, however, given Nixon's holding that the Senate is the final arbiter of impeachment trial procedures. ${ }^{179}$

The second argument is that the President has a special constitutional status that entitles him to a particular kind of impeachment trial. This argument is supported by the mandate that the Chief Justice preside over a presidential impeachment trial. Nevertheless, the need for finality and the difficulty of fashioning rehef counsel against justiciability. As the Court observed in Nixon, there would be considerable domestic and foreign strife "if the President were impeached. The legitimacy of any successor, and hence his effectiveness, would be impaired severely, not merely while the judicial process was running its course, but during any retrial that a differently constituted Senate might conduct if its first judgment of conviction were invalidated." 180 Even five seconds of uncertainty about who is properly the President of the United States would put national security at risk.

The reason for the uncertainty would be that there is no legitinate basis for a federal court to claim jurisdiction over a President's impeachment trial. To begin with, in the midst of debating the Supreme Court's jurisdiction on August 27, 1787, the

178. U.S. CONST. art. I, § 3 , cl. 6 .

179. Nixon, $113 \mathrm{~S}$. Ct. at 735-40.

180. Id. at 739. 
Constitutional Convention delegates "dropped 'impeachment' altogether from the list which later became, by stylistic revision, the list defining tlie Article III "judicial power."181 After initially agreeing to postpone considering whether to extend Supreme Court jurisdiction to "the trial of impeachments of officers of the United States,"182 the delegates considered the appropriate phrase or clause for accurately describing or designating the scope of the Supreme Court's jurisdiction. Madison "doubted whether it was not going too far to extend the jurisdiction of the Court generally to cases arising Under the Constitution, \& whetlier it ought not to be limited to cases of a Judiciary nature."183 After another delegate, Dr. Johnson, suggested "that the jurisdiction given [in the former phrase] was constructively limited to cases of a Judiciary nature," 184 the delegates agreed to postpone consideration of extending the Court's jurisdiction "im cases of impeachment." 185

The critical aspect of this debate is that it occurred in the umidst of the delegates' consideration of which cases, for whatever reason, would fall withm the jurisdiction of the Supreme Court. The Framers took great paims to set fortli as precisely as possible the kinds of cases they anticipated would fall properly within the Court's jurisdiction-those "of a Judiciary nature," as both Madison and Dr. Johnson put it. Not surprisingly, given that the Framers never regarded impeachments as constituting sucl cases, they balked at the prospect of mcluding either "the trial of impeachinents of officers of tlie United States" or "cases of impeachment" within the original or appellate n1atters that would fall within the jurisdiction of the Supreme Court.

The fact that the Framers understood that they would have liad to inake special mention of impeachments as falling within federal court jurisdiction in any manner nakes complete sense, given that judicial participation in the impeachment process had always been explicitly provided for $\mathrm{n}_{1}$ other jurisdictions with which they were familiar and that judicial review of impeachments would have deviated from the prevailing practice of their times. That the Framers dechned to make tlie extension tracked the com-

181. BLACK, supra note 13 , at 57 (citations omitted).

182. 2 RECORDS OF THE FEDERAL CONVENTION OF 1787, supra note 118, at 430 .

183. Id.

184. Id. at 431 .

185. Id. 
mon understanding that unless there were an explicit statement in the Constitution to the contrary, impeachments would remain, as they had always been up until then, cases of a unique nature not subject to judicial review.

Moreover, the Supreme Court could claim autliority over a presidential impeachment trial only if it had original or appellate jurisdiction over impeachments. The Court does not, however, have original jurisdiction over any kind of suit seeking to overturn a senatorial directive removing the President. ${ }^{186}$

It is also implausible that the Court has appellate jurisdiction over impeachments. The most likely portion of Article III granting the Supreme Court appellate jurisdiction over impeachments is that which covers "all Cases, in Law and Equity, arising under this Constitution ...." "187 The words "Law" and "Equity" are terms of art, referring to the two kinds of regular judicial courts in England and the United States at the time of the adoption of the Constitution. ${ }^{188}$ Impeachments are not technically im "Law" or "Equity."189 This construction is consistent with the underlying purpose of Article III, which has to do witlı regular judicial business in ordinary courts of law, except for a passage making it clear that jury trial is to play no part in impeachment. ${ }^{190}$ This latter provision was left in Article III when the Framers shifted responsibility for impeachment trials from the Supreme Court to the Senate, and therefore to Article I, dealing with the legislative branch. ${ }^{191}$ The Framers left this provision in place because its main purpose was to set forth a general rule of trial by jury, which logically belonged in the judiciary article, and they left in the reservation on impeachments to avoid any misunderstanding. In short, the inclusion of the term "impeachment" in Article III does not establisli that impeachment is in any way an Article III matter. ${ }^{192}$

\footnotetext{
186. See U.S. ConsT. art. III, $\S 2$, cl. 2.

187. Id. art. III, \& 2, cl. 1.

188. American Ins. Co. v. Canter, 26 U.S. (1 Pet.) 511, $544-45$ (1928).

189. Cf. WILSON, supra note 132 , at 426 (describing impeachments as proceedings of a political nature, "confined to political characters," charging only "political crimes and misdemeanors," and culminating only in "political punishments").

190. U.S. CONST. art. III, $\S 2$, cl. 3.

191. See BLACK, supra note 13 , at 56.

192. Another possible argument precluding judicial review of impeachments is that Congress, which has the power to "make" "[e]xceptions" to the Supreme Court's appellate jurisdiction, U.S. CONST. art. III, $\S 2$, cl. 2 ., has excepted snch appellate review by
} 
3. The Unrealistic Need for Judicial Review. To some, all of the difficulties with judicial review of impeachments might argue in favor of allowimg it only in the most extreme cases-i.e., some would argue that only the most minimal judicial review, around the outermost edges (however defined) of the process, makes sense. Otherwise, the Court needs to be prepared even in the case of a deviation from an explicit constraint to balance the need for judicial review against its effect on constitutional stability.

The counterargument to this contention is that it premises judicial review on an unrealistic basis. This is an appropriate attitude to adopt in determining the propriety of judicial intervention. ${ }^{193}$ The history of the federal impeachment power shows, for example, that even when attendance and preparation for an impeachment trial in the Senate have been poor, most senators have taken seriously (at least at the time they cast their final votes) the consequences of a conviction and have never considered failing to comply with-much less taken any steps toward violating-any of the exphicit constitutional constraints on their power to try impeachments. ${ }^{194}$ The fact that members of Congress have never

not providing for it in any statutes governing appeals to the Court. This contention is problematic for two reasons. First, interpreting Congress's failure to provide jurisdiction over impeachments to be an exception to appellate jurisdiction is risky. For example, it is plausible to construe Congress's failure as leaving intact the Court's appellate jurisdiction that otherwise exists (assuming that impeachment review does not fit within the language of any statute governing such jurisdiction). Second, Congress's power to except impeachment from appellate review presumably enables Congress to provide for such review if it so desires. This possibility raises a related question about whether Congress would then have the power to waive nonjusticiability. The resolution of this latter issue turns on the same factors as determining whether the Senate may waive the rule of nonjusticiability set forth in Nixon by adopting but not complying with particular procedural rules. See supra notes 168-74 and accompanying text. In any event, it would have been a waste of time and effort for the Framers to have given Congress the powers to impeach and to make exceptions to appellate jurisdiction over impeachments, because they then would have enabled Congress to undo their decision to move impeachment trials out of the Supreme Court and into the Senate. It seems odd that the Framers would have gone to all this trouble without mentioning that their decision could be reconsidered and overturned at any time by Congress.

193. See United States v. Lee, 106 U.S. 196, 217 (1882):

Hypothetical cases of great evils may be suggested by a particularly fruitful imagination in regard to almost every law upon which depend the rights of the individual or of the government, and if the existence of laws is to depend upon their capacity to withstand such criticism, the whole fabric of the law must fail. Cf. JOHN HART Ely, DEMOCRACY AND DISTRUST: A THEORY OF Judicial REviEw 183 (1980) ("[C]onstitutional law appropriately exists for those situations where representative government cannot be trusted, not those where we know it can.").

194. See generally Eleanore Bushnell, CRIMEs, Foldies, AND Misfortunes: THE 
conducted an impeachment proceeding in violation of any explicit restraint on the process sliows the degree to which those constraints, including the public pressure placed on Congress during an impeachment, liave achieved their desired effect.

Because they are so unlike anything actually ever tried in an impeachment, hypotlieticals about tossing coins or the Cliief Justice's failure to preside over a presidential impeachment trial do not supply reasonable bases for building reliable understandings of the justiciability of impeachment challenges. As Judge Stephen Williams observed in his opinion for the D.C. Circuit in Nixon,

If the Senate should ever be ready to abdicate its responsibilities to schoolchildren, or, moved by Caligula's appointment of his loorse as senator, to an elephant from the National Zoo, the republic will have sunk to depths from which no court could rescue it. And if the senators try to ignore the clear requirement of a two-thirds vote for conviction, they will have to contend with public outrage that will ultimately impose its sanction at the ballot box. Absent judicial review, the Senate takes sole responsibility for its impeachment procedures as a full-fledged constitutional actor, just as the framers intended. ${ }^{195}$

Given media scrutiny and party divisions, it is difficult to conceive low niembers of Congress would ever get away witl violating an explicit constraint on the impeachment power, especially in an event as closely watclied as a presidential impeachment. In short, the unlikeliliood that Congress will ever violate an explicit constraint on its impeachment power ${ }^{196}$ conveys something important about the continued effectiveness of current restraints and the similarly remote possibility that judicial review of the violation of an explicit constraint on impeachment would remedy the level of corruption or malfeasance that caused such a breach.

Federal IMPEACHMENT TRIALS (1992) (describing impeachment trials of 15 judges and other public officials). Of course, the plaintiff in Nixon regarded the term "try" as such a constraint, which was violated by the Senate's use of a trial committee. The Court claimed, however, that the impossibility of developing a clear, enforceable judicial construction of the word differentiated it from the explicit constraints on impeachment. Nixon v. United States, 113 S. Ct. 732, 736, 740 (1993).

195. Nixon v. United States, 938 F.2d 239, 246 (1991) (footnote omitted), aff'd, $113 \mathrm{~S}$. Ct. at 732 .

196. Cf. id. at 246 n.2 ("We need not decide [the permissibility of judicial review of the Senate's violation of an explicit constraint on its impeachment power], so we leave it for the unlikely day of its arising."). 


\section{CONCLUSION}

Nixon opened the way for better understanding of the connection between impeachments and the political question doctrine. On the one hand, it is clear after Nixon not only that the political question doctrine remains viable but also that it does so because it is based on constitutional text, structure, and history, as well as on prudent considerations about the consequences of judicial review. Moreover, in applying the doctrine to judicial impeachments, the Court in Nixon made a forceful statement about its own limits, that federal judges have no authority to review the procedures by which the Constitution pernnits their removal from office, and that there is not a judicial reinedy for every conceivable constitutional violation. ${ }^{197}$

On the other hand, the Nixon Court left Congress with nonreviewable authority to make pivotal decisions about its preferred procedures for removing solne of our most important federal officials. This prospect unsettles many people, who trust largely, if not exclusively, in the Court to make constitutional law. In other words, Nixon tells us that Congress too may make constitutional law. Of course, whether Congress has the authority to make judgments about the Constitution in the area of impeachment that are final $v i s-\grave{a}-v i s$ the other branches is a different issue from how well it makes constitutional law. Yet, it is fair to say that whatever one thinks of Nixon, the Court merely remained silent about something that has been going on without judicial review since the beginning of the republic. The fact that many constitutional law scholars were eager to end this practice says a great deal about their faith in judicial review. After Nixon, the time has come for these same people to (re)consider their faith in the Framers who did not trust any judicial involvenent with the administration of the federal impeachment process.

197. Cf. United States v. Butler, 297 U.S. 1, $87-88$ (1936) (Stone, J., dissenting) (arguing that "[c]ourts are not the only agency of government that must be assumed to have the capacity to govern" and rejecting the "assumption that the responsibility for the preservation of our institutions is the exclusive concern of any one of the three branches of government, or that it alone can save them from destruction"). 